The Latin American Subaltern Studies Reader 
A book in the series

Latin America Otherwise: Languages, Empires, Nations

Series editors

Walter D. Mignolo, Duke University

Irene Silverblatt, Duke University

Sonia Saldívar-Hull, University of California at Los Angeles 


\section{The Latin American}

\section{Subaltern Studies Reader}

Edited by Ileana Rodríguez

Duke University Press Durham and London 200I 
(C) 200I Duke University Press

All rights reserved

Printed in the United States of America on acid-free paper $\infty$

Typeset in Carter and Cone Galliard by Keystone Typesetting Inc.

Library of Congress Cataloging-in-Publication Data

appear on the last printed page of this book. 
To María Milagros López

(I950-I997)

In memory

Everything has to do with everything else

I lament the demise of my friend and colleague

María Milagros López. Raised in Puerto Rico and

educated in France, she had the grace of

transforming everyday life occurrences and funny

ready-made phrases into serious theoretical questions.

I miss her sharpness of mind and her sense

of pleasure and wit. 